\title{
PENGARUH KEPEMIMPINAN TRANSFORMASIONAL DAN MOTIVASI EKSTRINSIK TERHADAP KINERJA KARYAWAN \\ (STUDI PADA SALAH SATU PERUSAHAAN GARMEN DI KOTA BANDUNG)
}

\author{
Ira Rahayu Tarwiyah ${ }^{1}$, Nenny Rinawati ${ }^{2}$, Retno Resawati ${ }^{3}$, Adhie Fasha \\ Nurhadian $^{4}$ \\ Sekolah Tinggi Ilmu Ekonomi Pasundan, Bandung ${ }^{1,2,3,4}$ \\ Email: ira.rahayu.t@gmail.com ${ }^{1}$, nenny@ stiepas.ac.id ${ }^{2}$, retno@stiepas.ac.id ${ }^{3}$, \\ adhie@stiepas.ac.id ${ }^{4}$
}

\begin{abstract}
This research was carried based on the problems and the critical role of transformational leadership and extrinsic motivation in improving employee performance. To determine the effect of transformational leadership and extrinsic motivation on employee performance, the researchers conducted a survey on one of the garment companies in the city of Bandung with a simple random sampling technique of 67 employees. This study uses path analysis techniques to calculate the magnitude of the influence of transformational leadership and extrinsic motivation on employee performance either partially or simultaneously. The results showed that the real influence of transformational leadership was 47.4\%. In comparison, the total effect of extrinsic motivation was $25.0 \%$, so that the total effect was $72.4 \%$ with an epsilon of $27.6 \%$, which was another factor not investigated.
\end{abstract}

Keywords: transformational leadership, extrinsic motivation, employee performance.

\begin{abstract}
Abstrak
Berlatar belakang pada permasalahan dan peran penting dari kepemimpinan transformasional dan motivasi eksrinsik dalam meningkatkan kinerja karyawan
\end{abstract}


maka penelitian ini dilakukan. Untuk mengetahui pengaruh kepemimpinan transformasional dan motivasi eksrinsik terhadap kinerja karyawan maka peneliti melakukan survey pada salah satu perusahan garmen di Kota Bandung dengan teknik simple random sampling sebanyak 67 karyawan. Penelitian ini menggunakan teknik analisis jalur untuk menghitung besarnya pengaruh kepemimpinan transformasional dan motivasi eksrinsik terhadap kinerja karyawan baik secara parsial maupun simultan. Hasil penelitian menunjukkan bahwa total pengaruh kepemimpinan transformasional sebesar $47,4 \%$ sedangkan total pengaruh motivasi ekstrinsik sebesar $25,0 \%$ sehingga total pengaruh sebesar $72,4 \%$ dengan epsilon sebesar $27,6 \%$ yang merupakan factor lain yang tidak diteliti.

\section{Kata Kunci: kepempinan transformasional, motivasi ekstrinsik, kinerja karyawan.}

\section{PENDAHULUAN}

Kepemimpinan mempunyai hubungan yang erat dengan motivasi, karena keberhasilan seorang pemimpin dalam menggerakkan orang lain dalam mencapai tujuan yang telah ditetapkan sangat tergantung kepada kewibawaan dan kemampuan dalam menciptakan motivasi di dalam diri setiap bawahannya, kolega maupun atasan pemimpin itu sendiri. (Evans, 1970; Andersen, Bjørnholt, Bro \& Holm-Petersen, 2018).

Kepemimpinan transformasional diharapkan mampu menyebabkan timbulnya motivasi sehingga pengikut atau bawahannya memahami penting hasil dari pekerjaannya yang akan berdampak pada terciptanya rasa memiliki kebutuhan yang lebih tinggi, karena salah satu faktor yang dapat meningkatkan motivasi tidak hanya berasal dari dalam diri seseorang itu sendiri tetapi juga berasal dari dorongan luar diri seseorang atau pimpinan perusahaan. (Hadi \& Tola, 2019).

Kepemimpinan transformasional mempunyai dimensi kharismatik, stimulus intelektual, konsiderasi individual serta motivasi inspirasional. Jika pemimpin berhasil memengaruhi bawahannya dengan visinya, menanamkan karismanya, memotivasi dan menjadi inspirator, menstimulasi intelektual, kreatifitas dan menghargai karyawannya maka dapat dipastikan karyawan akan bekerja dengan baik, sungguh-sungguh dan loyal pada perusahaan sehingga kinerjanya meningkat. (Rafferty \& Griffin, 2004).

Menurut Bass \& Avolio (1993) menyatakan gaya kepemimpinan transformasional dapat membangkitkan atau memotivasi karyawan, sehingga dapat berkembang 
dan mencapai kinerja pada tingkat yang tinggi melebihi dari apa yang mereka perkirakan sebelumnya.

Sesuai dengan apa yang dikemukakan oleh Alshmemri, Shahwan-Akl \& Maude (2017) dan Manik \& Sidharta (2017) bahwa motivasi dapat berpengaruh terhadap hasil kinerja baik secara positif maupun negatif karena motivasi merupakan kekuatan potensial yang dapat dikembangkan berdasarkan dorongan kekuatan baik yang berasal dari diri sendiri maupun dari luar diri seseorang. Menurut Herzberg dalam teori motivasi dikenal dengan "Model 2 Faktor" yaitu motivasi intrinsik (berasal dari diri sendiri) dan motivasi ekstrinsik (berasal dari luar/perusahaan). (Holston-Okae \& Mushi, 2018)

Herzberg (2005) berpendapat bahwa apabila pekerja merasa puas dengan pekerjaannya, kepuasan itu didasarkan pada faktor-faktor intrinsik. Dan apabila para pekerja merasa tidak puas dengan pekerjaannya, ketidakpuasan itu pada umumnya dikaitkan dengan faktor-faktor yang sifatnya ekstrinsik.

Data prasurvey pada salah satu perusahaan garmen di Kota Bandung menunjukkan bahwa kepemimpinan transformasional dan motivasi ekstinsik serta kinerja karyawan masih belum memadai. Hal ini mengindikasikan terdapat permasalah pada kepemimpinan transformasional dan motivasi ekstinsik dalam meningkatkan kinerja karyawan.

Berdasarkan pada latar belakang peran pentinnya kepemimpinan transformasional dan motivasi ekstinsik yang telah dikemukakan sebelumnya, maka rumusan masalah yang diambil untuk penelitian ini adalah seberapa besar pengaruh kepemimpinan transformasional dan motivasi ekstrinsik secara parsial dan simultan terhadap kinerja karyawan.

\section{METODE PENELITIAN}

Metode penelitian yang digunakan adalah kuantitatif. Pendekatan kuantitatif adalah metode penelitian yang berlandaskan pada filsafat positivism, digunakan untuk meneliti pada populasi atau sampel tertentu.

Penulis melakukan penelitian pada salah satu perusahan garmen di Kota Bandung. Adapun lama penelitian menghabiskan waktu kurang lebih 4 bulan. Adapun sample dalam penelitian sebanyak 67 orang karyawan dengan menggunakan pendekatan simple random sampling dalam pemilihan responden penelitian. 
April , 2021

Operasional variabel dalam penelitian ini terdiri dari tiga variabel penelitian yaitu: Kepemimpinan Transformasional dengan dimensi Idealized Influence, Inspirational Motivation, Intellectual Stimulation, Individualized Consederation.

Motivasi Ekstrinsik dengan dimensi yaitu Kebijakan dan Administrasi, Kualitas Supervisi, Hubungan Antar Pribadi, Kondisi Kerja dan Gaji. Kinerja Karyawan dengan dimensi Kuantitas, Kualitas, Kerjasama, Tanggung Jawab dan Inisiatif.

Penelitian ini menggunakan analisis verifikatif yaitu suatu penelitian yang ditunjukan untuk menguji teori dan penelitian akan coba menghasilkan informasi ilmiah baru yaitu status hipotesis yang berupa kesimpulan apakah suatu hipotesis diterima atau ditolak. Dalam penelitian ini analisis verifikatif meliputi analisis korelasi, path analysis (analisis jalur) dan koefisien determinasi.

\section{HASIL DAN PEMBAHASAN}

Hasil perhitungan menunjukkan sebagai berikut:

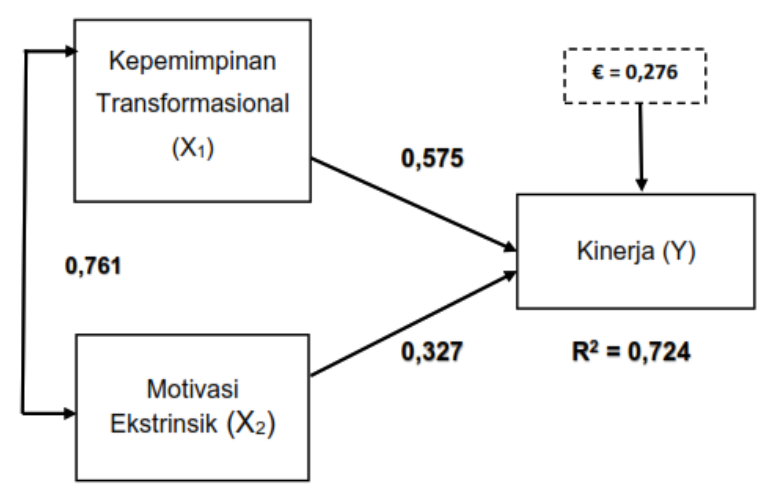

Gambar 1. Hasil perhitungan analisis jalur

Dari hasil perhitungan diketahui bahwa total pengaruh kepemimpinan transformasional sebesar $47,4 \%$ sedangkan total pengaruh motivasi ekstrinsik sebesar $25,0 \%$ sehingga total pengaruh sebesar 72,4\% dengan epsilon sebesar $27,6 \%$ yang merupakan factor lain yang tidak diteliti.

Berdasarkan hasil penelitian dan pengolahan data, Kepemimpinan Transformasional mempunyai pengaruh langsung 33,1\%, pengaruh tidak langsung melalui hubungannya dengan Variabel Motivasi Ekstrinsik sebesar 14,3\%, sehingga didapatkan total pengaruhnya adalah $47,4 \%$. Hasil penelitian ini mendukung penelitian yang dilakukan oleh

Berdasarkan hasil penelitian dan pengolahan data, Motivasi Ekstrinsik mempunyai pengaruh langsung 10,7\%, pengaruh tidak langsung melalui 
hubungannya dengan Variabel Kepemimpinan Transformasional sebesar 14,3\%, sehingga didapatkan total pengaruhnya adalah 25\%. Hasil penelitian ini mendukung penelitian yang dilakukan oleh

Berdasarkan hasil pengolahan data dan perhitungan koefisien determinasi $\left(\mathrm{R}^{2}\right)$ dengan nilai sebesar 0,724 atau $72,4 \%$ dan besarnya epsilon $\rho y \varepsilon=0,276$ atau $27,6 \%$, yang artinya bahwa variabel Kepemimpinan Transformasional dan Motivasi Ekstrinsik secara bersama-sama mempengaruhi Kinerja Karyawan sebesar 0,724 atau 72,4\%, untuk faktor lain yang yang mempengaruhi kinerja karyawan selain dari pada Kepemimpinan Transformasional dan Motivasi Ekstrinsik atau variabel lain yang tidak diteliti memiliki nilai variabel epsilon sebesar 0,276 atau 27,6\%. Hasil penelitian ini mendukung penelitian yang dilakukan oleh Hadi \& Tola (2019) dan Andersen, Bjørnholt, Bro \& HolmPetersen (2018) membuktikan bahwa kepemimpinan dan motivasi dapat berdampak pada kinerja karyawan.

\section{KESIMPULAN}

Berdasarkan hasil analisis statistik dan pembahasan sebelumnya mengenai pengaruh Kepemimpinan Transformasional dan Motivasi Ekstrinsik terhadap Kinerja Karyawan dapat diambil kesimpulan bahwa Kepemimpinan Transformasional dan Motivasi Ekstrinsik secara parsial dan simultan berpengaruh terhadap Kinerja Karyawan.

Untuk meningkatkan Kepemimpinan Transformasional, sebaiknya pimpinan lebih meningkatkan ketegasan sikap dalam mengambil keputusan, memberikan arahan, bimbingan, petunjuk serta evaluasi berkenaan pelaksanaan tugas dan pekerjaan sehingga bawahan dapat lebih menghargai peran dari seorang pemimpin itu sendiri. Selain itu pimpinan juga harus bisa lebih menghargai setiap hasil pekerjaan bawahannya sebab dengan adanya apresiasi akan membuat bawahan senang dan semakin semangat dalam bekerja. Karena dengan dihargai, para bawahan juga akan merasa diperhartikan dan diakui pentingnya keberadaan mereka bagi pimpinannya maupun perusahaan.

Untuk meningkatkan Motivasi Ekstrinsik, sebaiknya perusahaan harus meningkatkan kualitas supervisi misalnya para pimpinan harus benar-benar memahami tugas dan tanggung jawabnya, apa saja yang harus dilakukan dan tidak boleh dilakukan termasuk harus bersikap objektif terhadap semua bawahannya dengan tidak membeda-bedakan sikap karena pemimpin harus mengayomi seluruh bawahannya dan menempatkannya dalam kedudukan yang sama. Selain itu dengan memberikan reward berupa insentif sesuai hasil pekerjaan 
karyawannya sehingga karyawan merasa terpuaskan akan hasil pekerjaannya yang akan mengarah pada meningkatnya loyalitas karyawan terhadap perusahaan.

\section{REFERENSI}

Alshmemri, M., Shahwan-Akl, L., \& Maude, P. (2017). Herzberg's two-factor theory. Life Science Journal, 14(5), 12-16.

Andersen, L. B., Bjørnholt, B., Bro, L. L., \& Holm-Petersen, C. (2018). Leadership and motivation: A qualitative study of transformational leadership and public service motivation. International Review of Administrative Sciences, 84(4), 675-691.

Bass, B. M., \& Avolio, B. J. (1993). Transformational leadership: A response to critiques. In M. M. Chemers \& R. Ayman (Eds.), Leadership theory and research: Perspectives and directions (pp. 49-80). Academic Press.

Evans, M. G. (1970). Leadership and motivation: A core concept. Academy of management journal, 13(1), 91-102.

Hadi, T. P., \& Tola, B. (2019). The Effect of Transformational Leadership and Work Motivation on Innovative Behavior. IJHCM (International Journal of Human Capital Management), 3(2), 100-108.

Holston-Okae, B. L., \& Mushi, R. J. (2018). Employee turnover in the hospitality industry using Herzberg's two-factor motivation-hygiene theory. International Journal of Academic Research in Business and Social Sciences, 8(1), 218-248.

Herzberg, F. (2005). The motivation-hygiene theory. Organizational behavior one: Essential theories of motivation and leadership, eds JB Miner, ME Sharpe Inc, New York, 61-74.

Manik, E., \& Sidharta, I. (2017). The Impact of Motivation, Ability, Role Perception on Employee Performance and Situational Factor as Moderating Variable of Public Agency in Bandung, Indonesia. International Journal of Management Science and Business Administration, 3(4), 65-73.

Rafferty, A. E., \& Griffin, M. A. (2004). Dimensions of transformational leadership: Conceptual and empirical extensions. The leadership quarterly, 15(3), 329-354. 
April , 2021

Bisnis Dan Iptek | Sekolah Tinggi Ilmu Ekonomi Pasundan Bandung 